\title{
GAMBARAN SANITASI DASAR PADA SEKOLAH DASAR DI KECAMATAN WAYHALIM KOTA BANDAR LAMPUNG
}

\author{
Bella Pratika Riyan Sari ${ }^{1)}$
}

\begin{abstract}
Abstrak
Sanitasi Dasar sekolah adalah syarat kesehatan lingkungan minimal yang harus dipunyai oleh setiap sekolah untuk memenuhi kebutuhan siswa (i). Ruang lingkup sanitasi dasar yakni sarana penyediaan air bersih, sarana jamban, sarana pembuangan sampah, dan sarana pembuangan air limbah. Fungsi dari sanitasi dasar pada sekolah dasar yaitu sebagai upaya untuk pencegahan penyakit penyakit yang berbasis lingkungan, untuk membantu peran tenaga kesehatan dalam mempromosikan kesehatan kepada anak sekolah dasar. Tujuan Penelitian diketahuinya gambaran sanitasi dasar pada sekolah dasar di Kecamatan Wayhalim Kota Bandar Lampung.

Penelitian ini bersifat deskriptif yang dilakukan di seluruh sekolah dasar $(n=14)$ di Kecamatan Wayhalim Kota Bandar Lampung. Pengumpulan data dengan pengukuran, observasi dan wawancara. Penelitian dilaksanakan selama bulan Februari-Mei 2017.

Hasil penelitian mendapatkan bahwa sarana air bersih menggunakan sumur bor $(71,4 \%)$, sumur gali $(21,4 \%)$, dan PDAM (7,1\%). Seluruh sekolah memiliki toilet atau urinoir dan sebagian terpisah antara laki-laki dan perempuan. Sebanyak $57,14 \%$ sckolah dasar menggunakan SPAL yang tidak tertutup sehingga menjadi tempat perindukan vektor. Seluruh sekolah telah memiliki tempat penampungan sampah.
\end{abstract}

Kata Kunci: Air bersih, kotoran manusia, sampah, air limbah

${ }^{1)}$ Alumni Prodi D3 Kesehatan Lingkungan Poltekkes Tanjungkarang

\section{PENDAHULUAN}

Kesehatan merupakan kebutuhan yang sangat penting bagi kehidupan manusia, dalam keadaan sehat manusia dapat melakukan banyak hal yang berkaitan dengan kepentingan pribadi maupun kepentingan orang banyak. Kesehatan manusia dapat dipengaruhi berbagai macam faktor seperti lingkungan, perilaku masyarakat, pelayanan kesehatan hingga genetika yang ada di lingkungan atau masyarakat itu sendiri. Maka dari itu kesehatan harus diperhatikan untuk kemajuan suatu bangsa selain pendidikan dan ekonomi. Lingkungan adalah segala sesuatu yang ada di sekitar kehidupan yang dapat mempengaruhi kesehatan. Lingkungan yang tidak sehat dapat menyebabkan timbulnya berbagai macam penyakit. Maka dari itu untuk menaggulangi dampak lingkungan yang tidak sehat perlu dilakukan pendidikan yang merupakan hal penting dalam dunia kesehatan terutama kesehatan lingkungan. Sebaiknya hal ini diajarkan sedini mungkin agar tidak berdampak buruk bagi kesehatan.
Masalah kesehatan adalah suatu masalah yang sangat kompleks, yang saling berkaitan dengan masalah-masalah lain diluar kesehatan sendiri. Demikian pula pemecahan masalah kesehatan masyarakat, tidak hanya dilihat dari segi kesehatannya, tapi harus dilihat dari segisegi yang ada pengaruhnya terhadap masalah 'sehat-sakit' atau kesehatan tersebut. Keempat faktor tersebut adalah lingkungan, prilaku, pelayanan kesehatan dan hereditas (keturunan) disamping berpengaruh satu sama lainnya, status kesehatan akan tercapai secara optimal, bilamana keempat faktor tersebut secara bersama-sama memiliki kondisi yang optimal, salah satu faktor berada dalam keadaan terganggu (tidak optimal), maka status kesehatan akan tergeser di bawah optimal (Notoatmodjo:2011).

Menurut Hendrik L. Blum derajat kesehatan di pengaruhi oleh 4 ( empat ) faktor yaitu: lingkungan, prilaku, pelayanan kesehatan dan keturunan. Dari keempat faktor tersebut, di Negara yang sedang berkembang, faktor lingkungan dan faktor prilaku mempunyai 
peranan yang sangat besar disamping faktorfaktor lainya terhadap peningkatan derajat kesehatan masyarakat.

Kesehatan lingkungan pada hakikatnya adalah suatu kondisi atau kaadaan yang optimum sehingga berpengaruh positif terhadap terwujudnya status kesehatan yang optimum pula. Jika keschatan lingkungan tidak baik, akan berpengaruh terhadap kesehatan masyarakat (Notoatmodjo, 2011). Lingkungan dapat dikategorikan dalam tiga bagian yaitu lingkungan fisik (antara lain tanah, air dan udara), lingkungan biologi (hewan, tumbuhan, maupun mikroorganisme kecuali manusia), dan lingkungan sosial (tersamuk semua interaksi antar manusia dengan manusia, dalam bentuk hubungan kemasyarakatan).

Untuk meningkatkan status kesehatan perlu dilakukan upaya penyehatan lingkungan yang merupkan usaha pencegahan terhadap penyakit yang berhubungan dengan lingkungan hidup. Jika kesehatan lingkungan tidak baik, maka akan mendatangkan penyakit bagi masyarakat, sekolah dan akan dapat mempengaruhi proses belajar dan menagajar. Jika tidak dapat diatasi maka akan merugikan kehidupan bangsa.

Sekolah merupakan perpanjang tangan orang tua, bukan saja tempat menanamkan norma-norma kehidupan sosial, tetapi juga menanamkan dan mengembangkan kemampuan hidup untuk memasuki dunia kerja. Untuk itu maka sekolah juga harus menjadi lingkungan yang kondusif bagi terbentuknya dan berkembangnya perilaku hidup sehat (Notoatmodjo, 2012).

Sekolah dasar adalah proses pendidikan yang diberikan kepada anak didik yang mendasari setiap pendidikan selanjutnya. Sckolah merupakan tempat berkumpulnya siswa dan warga sekolah dalam kegiatan proses belajar dan mengajar. Sebagian waktu anakanak dihabiskan dilingkungan sekolah, oleh karenanya lingkungan sekolah yang aman, nyaman dan sehat sangat diperlukan. Sanitasi lingkungan sekolah lebih menekankan pada upaya pengawasan dan pengendalian pada faktor lingkungan fisik. Seperti keberadaan sekolah, penyediaan air bersih yang memenuhi syarat fisik, tempat pembuangan kotoran, pembuangan limbah dan kondisi halaman.

Tujuan upaya kesehatan sekolah adalah untuk meningkatkan mutu pendidikan dan prestasi belajar peserta didik dengan meningkatkan perilaku hidup bersih dan sehat serta derajat kesehatan dan menciptakan lingkungan yang sehat (Notoatmodjo,2 012). Mengingat sekolah merupakan sekelompok masyarakat yang mempunyai andil besar dalam kelangsungan negara ini, maka perlu diperhatikan dan ditingkatkan kemampuan hidup sehat peserta didik melalui salah satunya menciptakan lingkungan sekolah yang schat sehingga peserta didik dapat belajar tumbuh dan berkembang secara harmonis dan optimal yang nantinya akan menghasilkan sumber daya manusia yang berkualitas, dalam skala yang lebih kecil, sanitasi sekolah juga cenderung dilupakan kondisi kebersihannya. Padahal kondisi sanitasi yang buruk dapat menyebabkan berbagai dampak. Diantaranya, rendahnya efektivitas dalam kegiatan belajar, tingkat absensi tinggi, tingginya prevalensi penyakit.

Bedasarkan hasil studi awal pada seluruh sekolah dasar di Kecamatan Wayhalim Kota Bandar Lampung (14 sekolah), terlihat bahwa masih banyak sarana sanitasi dasar yang belum memenuhi syarat, yaitu sarana air bersih, toilet atau jamban, vektor, saluran pembuangan air limbah (SPAL), dan penanganan sampah. Penelitian bertujuan mendapatkan gambaran sanitasi dasar pada sekolah dasar di Kecamatan Wayhalim Kota Bandar Lampung.

\section{METODE}

Jenis penelitian ini bersifat deskriptif, yaitu suatu metode penelitian yang bertujuan untuk membuat gambaran/deskripsi tentang suatu kejadian objektif, yaitu sarana sanitasi dasar pada seluruh sekolah dasar di Kecamatan Wayhalim Kota Bandar Lampung.

Populasi penelitian sebanyak 14 sekolah dasar, terdiri dari 10 sekolah dasar negeri dan 4 sekolah dasar swasta. Tidak dilakukan pengambilan sampel, sehingga dilakukan penilaian terhadap seluruh populasi. Pengumpulan data dilakukan dengan pengukuran, pengamatan (observasi) menggunakan checklist dan wawancara (interview) dengan quisoner.

Pengolahan data dilakukan secara manual dan disajikan dalam bentuk tabel dan narasi dan dibandingkan dengan KEPMENKES RI No.1429 Tahun 2006, tentang pedoman penyelenggaraan kesehatan lingkungan sekolah.

\section{HASIL}

\section{Sarana Penyediaan Air Bersih}

Bedasarkan Tabel 1 terlihat bahwa sebanyak $71,4 \%$ sekolah dasar menggunakan sumur bor, 
$21,4 \%$ menggunakan sumur gali/pompa, dan $7,1 \%$ yang menggunakan PDAM.

Berdasarkan Table 2, seluruh sekolah dasar di Kecamatan Wayhalim Kota Bandar Lampung memiliki kapasitas air bersih sebanyak $15 \mathrm{~L} /$ orang/hari. Ditemukan 8 sekolah dasar yang tidak memenuhi syarat berdasarkan kecukupan air bersih.
Tabel 1.Sarana Penyediaan Air Bersih

\begin{tabular}{lcc}
\hline \multicolumn{1}{c}{ Sarana Air Bersih } & $\mathrm{n}$ & $\%$ \\
\hline Sumur Gali/Pompa & 12 & 85,7 \\
PDAM & 13 & 92,9 \\
Lain-lain (Sumur Bor) & 11 & 78,6 \\
Jumlah & 14 & $100 \%$ \\
\hline
\end{tabular}

Tabel 2. Jumlah dan Kapasitas Air Bersih Pada Sekolah Dasar Di Se-Kecamatan Wayhalim

\begin{tabular}{clcccc}
\hline No & \multicolumn{1}{c}{ Nama Sekolah } & $\begin{array}{c}\text { Jumlah } \\
\text { siswa }\end{array}$ & $\begin{array}{c}\text { Kapasitas air } \\
\text { (liter/org/hari) }\end{array}$ & $\begin{array}{c}\text { Kebutuhan } \\
\text { Air/Hari }\end{array}$ & Ket \\
\hline 1. & SD Negeri 1 Perumnas Wayhalim & 421 & 15 & 6.315 Liter & TMS \\
2. & SD Negeri 2 Perumnas Wayhalim & 751 & 15 & 11.265 Liter & TMS \\
3. & SD Negeri 3 Perumnas Wayhalim & 279 & 15 & 4.185 Liter & TMS \\
4. & SD Negeri 1 Wayhalim Permai & 338 & 15 & 5.070 Liter & TMS \\
5. & SD Negeri 2 Wayhalim Permai & 468 & 15 & 7.020 Liter & TMS \\
6. & SD Negeri 1 Gunung Sulah & 364 & 15 & 5.460 Liter & TMS \\
7. & SD Negeri 2 Gunung Sulah & 361 & 15 & 5.415 Liter & TMS \\
8. & SD Negeri 1 Jagabaya 1 & 232 & 15 & 1.635 Liter & MS \\
9. & SD Negeri 1 Jagabaya III & 263 & 15 & 3.945 Liter & MS \\
10. & SD Negeri 3 Jagabaya 1 & 109 & 15 & 1.635 Liter & MS \\
11. & SD Al-Azhar 1 & 752 & 15 & 11.280 Liter & MS \\
12. & SD Al-Azhar 2 & 778 & 15 & 11.670 Liter & MS \\
13. & SD Xaverius 3 Wayhalim & 802 & 15 & 12.030 Liter & TMS \\
14. & SLB Growing Hope & 115 & 15 & 1.725 Liter & MS \\
\hline
\end{tabular}

Pada Table 3 terlihat bahwa sumur bor yang jaraknya terhadap sumber pencemar tidak memenuhi syarat sebanyak $14,3 \%$, kualitas air keruh dan bau $(7,1)$. Sebanyak 21,4 sumur bor menggunakan pipa untuk memompa, dan 50\% terdapat pelindung di bawah pompa air.

Hasil penelitian juga mendapatkan bahwa konstruksi sumur gali tidak memenuhi syarat konstruksi, yaitu jarak dari sumber pencemaran kurang dari $10 \mathrm{~m}$, dinding sumur kurang dari 3 $\mathrm{m}$, dan pengambilan air menggunakan pompa tangan atau listrik sumur tidak ditutup rapat. Berdasarkan kualitas fisik, seluruh air bersih telah memenuhi syarat kesehatan.

Tabei 3. Kontruksi Sumber Air Bersih

\begin{tabular}{lcccc}
\hline \multicolumn{1}{c}{ Kontruksi Sumur } & \multicolumn{2}{c}{ MS } & \multicolumn{2}{c}{ TMS } \\
\cline { 2 - 5 } & $\mathrm{n}$ & $\%$ & $\mathrm{n}$ & $\%$ \\
\hline Sumur Bor & 12 & 85,7 & 2 & 14,3 \\
Jarak 95 m dari sumber pencemar & 13 & 92,9 & 1 & 7,1 \\
Tidak keruh dan bau & 11 & 78,6 & 3 & 21,4 \\
Terdapat pipa untuk memompa & 7 & 50 & 7 & 50 \\
Terdapat pelindung & 12 & 85,7 & 2 & 14,3 \\
Sumur Gali & 10 & 71,4 & 4 & 28,6 \\
Jarak sumur min 10 m dari sumber pencemaran & 13 & 92,9 & 1 & 7,1 \\
Lantai harus kedap air & 12 & 85,7 & 2 & 14,3 \\
Lebar lantai min 1 m dari dinding sumur & 10 & 71,4 & 4 & 28,6 \\
Tinggi bibir sumur 70 cm dari lantai & 12 & 85,7 & 2 & 14,3 \\
Kedalaman dinding sumur min 3 m & 12 & 85,7 & 2 & 14,3 \\
Dinding kedap air & 12 & 85,7 & 2 & 14,3 \\
Sumur harus ditutup rapat (jika menggunakan pompa) & 4 & 28,6 & 10 & 71,4 \\
Timba di gantung (jika menggunakan timba) & 14 & 100 & - & - \\
Kualitas fiik air (tidak keruh dan berwarna) & & & & \\
\hline
\end{tabular}

\section{Pembuangan Kotoran Manusia}


Bedasarkan Tabel 4 dapat diketahui bahwa sarana pembuangan tinja atau urinoir yang tidak memenuhi syarat kebersihan sebanyak $42,9 \%$, tidak tersedia lubang penghawaan yang langsung berhubungan dengan udara luar $(28,6 \%)$, dan bak penampung air menjadi tempat perindukan nyamuk $(42,9 \%)$.
Sedangkan jenis sarana, seluruhnya berupa jamban leher angsa.

Berdasarkan Tabel 5 dapat dilihat bahwa hanya tiga sckolah (20\%) yang jumlah ketersediaan jamban atau urinoir memenuhi syarat. Sisanya belum memenuhi persyaratarn keschatan, yaitu 1:40 (putra) dan 1:25 (putri).

Tabel 4. Kualitas Sarana Pembuangan Tinja dan Urinoir

\begin{tabular}{lcccc}
\hline \multirow{2}{*}{ Pembuangan Tinja atau Urinoir } & \multicolumn{2}{c}{ MS } & \multicolumn{2}{c}{ TMS } \\
\cline { 2 - 5 } & $\mathrm{n}$ & $\%$ & $\mathrm{n}$ & $\%$ \\
\hline Toilet dalam keadaan bersih & 8 & 57,1 & 6 & 42,9 \\
Lantai kedap air & 13 & 92,9 & 1 & 7,1 \\
Tersedia lubang penghawaan & 10 & 71,4 & 4 & 28,6 \\
Bak penampung air tidak menjadi tempat perindukan & 8 & 57,1 & 6 & 42,9 \\
Jamban Leher Angsa & 14 & 100 & - & - \\
\hline
\end{tabular}

Tabel 5. Kapasitas Proporsi Pengguna Toilet

\begin{tabular}{llccccccccc}
\hline \multirow{2}{*}{ No } & \multirow{2}{*}{ Nama Sekolah } & \multicolumn{3}{c}{ Jumlah siswa } & \multicolumn{3}{c}{ Jumlah jamban } & \multicolumn{2}{c}{ Rasio } & Ket \\
\cline { 3 - 10 } & & L & P & L & P & $\begin{array}{c}\text { Meny } \\
\text { atu }\end{array}$ & L & P & MS \\
\hline 1. & SD Negeri I Perumnas Wayhalim & 381 & 466 & 1 & 1 & - & $1: 381$ & $1: 466$ & TMS \\
2. & SD Negeri 2 Perumnas Wayhalim & 128 & 110 & 2 & 2 & - & $1: 64$ & $1: 55$ & TMS \\
3. & SD Negeri 3 Perumnas Wayhalim & 80 & 176 & 1 & 1 & - & $1: 80$ & $1: 176$ & TMS \\
4. & SD Negeri 1 Wayhalim Permai & 131 & 127 & 1 & 1 & - & $1: 131$ & $1: 127$ & TMS \\
5. & SD Negeri 2 Wayhalim Permai & 166 & 152 & 1 & 1 & - & $1: 166$ & $1: 152$ & TMS \\
6. & SD Negeri 1 Gunung Sulah & 161 & 103 & - & - & 2 & - & - & TMS \\
7. & SD Negeri 2 Gunung Sulah & 184 & 156 & 2 & 2 & - & $1: 92$ & $1: 78$ & MS \\
8. & SD Negeri 1 Jagabaya 1 & 98 & 115 & - & - & 2 & - & - & TMS \\
9. & SD Negeri 1 Jagabaya III & 148 & 96 & 1 & 1 & - & $1: 148$ & $1: 96$ & TMS \\
10. & SD Negeri 3 Jagabaya 1 & 125 & 213 & - & - & 3 & - & - & TMS \\
11. & SD Al-Azhar 1 & 663 & 619 & 16 & 17 & - & $1: 41$ & $1: 36$ & TMS \\
12. & SD Al-Azhar 2 & 689 & 574 & 16 & 17 & - & $1: 43$ & $1: 34$ & TMS \\
13. & SD Xaverius 3 Wayhalim & 296 & 260 & 11 & 11 & - & $1: 27$ & $1: 24$ & MS \\
14. & SLB Growing Hope & 50 & 65 & 3 & 3 & - & $1: 17$ & $1: 22$ & MS \\
\hline
\end{tabular}

Keterangan jumlah wc/urinoir (Sumber : KepMenKes RI 1429/MenKes/SK/XII/2006)

a. Proporsi $1 \mathrm{wc} /$ urinoir untuk 40 orang siswa

b. Proporsi 1 wc/urinoir untuk 25 orang siswi

\section{Pembuangan Sampah}

Berdasarkan Tabel 6 bahwa sebagian besar sarana pembuangan sampah tidak memenuhi syarat, yaitu tidak tersedia tempat sampah tertutup di setiap ruangan $(50 \%)$, tidak mempunyai TPS $(14,3 \%)$, jarak TPS dengan ruang kclas $<10 \mathrm{~m}(57,1 \%)$, dan tidak ada pemisahan tempat sampah organik dan anorganik (50\%).
Sedangkan berdasarkan konstruksinya, sebagian besar telah memenuhi syarat kesehatan, yaitu kuat, kedap air, tahan karat, mudah dibersihkan, dan mudah diangkut. Namun masih ditemukan sekolah dasar yang menngunakan tempat sampah yang tidak memiliki tutup $(50 \%)$. 
Tabel 6. Sarana Pembuangan Sampah

\begin{tabular}{|c|c|c|c|c|}
\hline \multirow{2}{*}{ Pembuangan Sampah } & \multicolumn{2}{|c|}{ MS } & \multicolumn{2}{|c|}{ TMS } \\
\hline & $\mathrm{n}$ & $\%$ & $\mathrm{n}$ & $\%$ \\
\hline \multicolumn{5}{|l|}{ Sistem Pengelolaan Sampah } \\
\hline Tersedia tempat sampah tertutup di setiap ruangan & 7 & 50 & 7 & 50 \\
\hline Tersedia tempat pengumpulan sampah sementara (TPS) & 12 & 85,7 & 2 & 14,3 \\
\hline Jarak TPS dengan ruang kelas minimal $10 \mathrm{~m}$ & 6 & 42,9 & 8 & 57,1 \\
\hline Pemisahan tempat sampah organik dan anorganik & 7 & 50 & 7 & 50 \\
\hline \multicolumn{5}{|l|}{ Konstruksi Tempat Sampah } \\
\hline Kuat & & & & s \\
\hline Kedap air & 7 & 50 & 7 & 50 \\
\hline Tahan karat & 13 & 92,9 & 1 & 7,1 \\
\hline Mudah di bersihkan & 13 & 92,9 & 1 & 7,1 \\
\hline Mudah diangkut & 13 & 92,9 & 1 & 7,1 \\
\hline Memiliki tutup & 13 & 92,9 & 1 & 7,1 \\
\hline
\end{tabular}

\section{Pembuangan Air Limbah}

Berdasarkan Tabel 7 terlihat bahwa saluran air limbah yang umumnya tidak memenuhi syarat adalah tidak terpisah dengan saluran air hujan $(42,9 \%)$, tidak tertutup terdapat $(50 \%)$, mencemari lingkungan (35,7\%), air limbah tidak mengalir dengan lancar $(21,4 \%)$, tidak dibuang melalui tangki septic dan peresapan $(7,1 \%)$, serta tidak memiliki bak control $(78,6 \%)$.

Tabel 7. Saluran pembuangan Air Limbah

\begin{tabular}{lcccc}
\hline \multicolumn{1}{c}{ Saluran Pembuangan Air Limbah } & \multicolumn{2}{c}{ MS } & \multicolumn{2}{c}{ TMS } \\
\cline { 2 - 5 } & $\mathrm{n}$ & $\%$ & $\mathrm{n}$ & $\%$ \\
\hline Saluran pembuangan air limbah yang terpisah dengan saluran air hujan & 8 & 57,1 & 6 & 42,9 \\
Saluran air limbah kedap air & 11 & 78,6 & 3 & 21,4 \\
Saluran air limbah tertutup & 7 & 50 & 7 & 50 \\
SPAL tidak mencemari lingkungan & 9 & 64,3 & 5 & 35,7 \\
Air limbah mengalir dengan lancar & 11 & 78,6 & 3 & 21,4 \\
Air limbah dibuang melalui septik dan peresapan & 13 & 92,9 & 1 & 7,1 \\
Saluran pembuangan air limbah memiliki bak control & 3 & 21,4 & 11 & 78,6 \\
\hline
\end{tabular}

\section{PEMBAHASAN}

\section{Sarana Penyediaan Air Bersih}

Berdasarkan hasil penelitian terdapat $71,4 \%$ sekolah dasar yang menggunakan sumur bor, $21,4 \%$ menggunakan sumur gali, dan $7,1 \%$ menggunakan PDAM. Secara kuantitas air bersih pada umumnya sudah mencukupi kebutuhan setiap harinya. Hasil wawancara dengan pihak sekolah juga menyampaikan bahwa sumber air tidak pernah kering dan penampungan air selalu terisi secara kontinyu.

Kualitas fisik air di seluruh sekolah dasar di Kecamatan Wayhalim seluruhnya telah memenuhi syarat kesehatan yaitu tidak berbau, tidak berasa, dan tidak berwarna (sesuai dengan Permenkes No. 416 tahun 1990 tentang pengawasan kualitas air bersih). Jarak sumber air bersih dengan sumber pencemaran lebih dari 10 meter terdapat pada 3 sekolah, sedangkan yang kurang dari 10 meter pada 4 sekolah. Jika jarak sumber air bersih dengan sumber pencemaran kurang dari 10 meter maka sumber air bersih menjadi tercemar. Bakteri dari sumber pencemar dapat menembus tanah maksimal sedalam 3 meter dan sejauh 10 meter.

Menurut Keputusan Menteri Kesehatan RI Nomor 1429 tahun 2006, sarana air bersih harus memenuhi persyaratan, yaitu tersedia air bersih $15 \mathrm{~L} /$ orang/hari, kualitas air bersih memenuhi syarat kesehatan yang sesuai dengan Kepmenkes No. 416 tahun 1990, jarak sumur atau sarana air bersih dengan sumber pencemaran (sarana pembuangan air limbah, septi tank, tempat pembuangan sampah akhir) minimal 10 meter.

Bedasarkan hasil observasi, ditemukan konstruksi sumur yang tidak memenuhi syarat kesehatan seperti lantai tidak kedap air dan lantai retak-retak. Hal tersebut bisa menyebabkan pencemaran air melalui rembesan atau resapan ke dalam tanah. Lantai minimal 1 meter dari dinding sumur, hal ini untuk 
mencegah terjadinya pencemaran air melalui rembesan di sekeliling sumber air bersih. Sedangkan tinggi bibir sumur minimal 70-100 $\mathrm{cm}$, untuk mencegah terjadinya kecelakaan.

Untuk menghindari terjadinya pencemaran terhadap air dan mencegah terjadinya penyebaran penyakit, maka beberapa persyaratan yang harus diperhatikan adalah (Notiatmodjo, 2011):

a. Jarak sarana air bersih dengan sumber pencemaran minimal 10 meter.

b. Lantai harus kedap air minimal 1 meter dari dinding sumur, mudah dibersihkan dan tidak tergenang air.

c. Dinding sumur minimal sedalam 3 meter dari permukaan.

d. Tinggi bibir sumur $70 \mathrm{~cm}$ dari lantai.

e. Jika pengambilan air dengan menggunakan timba, harus ada timbang khusus untuk mencegah pencemaran, dan timba harus digantung serta tidak boleh diletakkan dilantai.

f. Jika pengambilan air dengan pompa tangan atau listrik sebaiknya sumur harus ditutup rapat untuk menghindari pencemaran.

Jika kontruksi sumur gali mengalami kerusakan seperti lantai dan dinding mengalami keretakan, harus segera dilakukan perbaikan untuk mencegah terjadinya pencemaran pada sumber air. Timba diberi gantungan dari bambu atau bahan lain yang dapat mencegah kontak lansung antara ember dengan lantai, apabila setelah digunakan agar tidak diletakkan dilantai.

\section{Pembuangan Kotoran Manusia (Toilet)}

Bedasarkan hasil penelitian diketahui bahwa seluruh sekolah dasar di Kecamatan Wayhalim telah memiliki toilet atau urinoir, dan letaknya sebagian sudah terpisah dengan ruangan lain, serta terpisah antara laki-laki dan perempuan. Namun, masih ditemukan keadaan toilet yang tidak bersih, serta belum terpisah antara toilet laki-laki dan perempuan. Berdasarkan konstruksinya, masih banyak ditemukan lantai yang tidak kedap air, dan tidak terdapat lubang penghawaan untuk menjamin terjadinya sirkulasi udara.

Menurut Keputusan Menteri Kesehatan RI Nomor 1429 tahun 2006, toilet atau urinoir harus memenuhi persyaratan sebagai berikut:

a. Letak toilet harus terpisah dari ruang kelas, ruang UKS, ruang guru, perpustakaan, ruang bimbingan dan konseling. b. Tersedia toilet terpisah antara laki-laki dan perempuan.

c. Proporsi jumlah wc/urinoir adalah 1 we/urinior untuk 40 siswa dan 1 we untuk 25 siswi

d. Toilet harus dalam keadaan bersih.

e. Lantai toilet tidak ada genangan air.

f. Tersedia lubang penghawaan yang langsung berhubungan dengan udara luar.

g. Bak penampung air harus tidak menjadi tempat perindukan nyamuk.

Pembuangan tinja yang tidak saniter dapat menyebabkan penyebaran berbagai macam penyakit. Tinja yang mengandung agent penyakit akan mencemari air tanah, atau melalui serangga vektor (kecoa, lalat) yang hinggap pada makanan. Penyakit-penyakit seperti typus abdominalis, kolera, disentri basiler, amuba, hepatitis infektiosa, serta berbagai jenis cacing, dapat di sebarkan melalui air. Untuk menghindarinya, beberapa hal yang harus diperhatikan (Ircham, 1992):

a. Tidak mengontaminasi tanah.

b. Tidak mengontaminasi sumber air tanah.

c. Tidak mengontaminasi air permukaan.

d. Tidak dapat dicapai berbagai hewan seperti lalat, kecoak, dan tikus.

e. Tidak menyebabkan bau yang mengganggu kesehatan estetis.

f. Pengangkutan dalam bentuk segar harus dihindari.

Hal-hal yang harus diperhatikan dalam membangun sebuah kakus atau jamban yang harus dipenuhi diantaranya: 1). Harus tertutup, dalam arti bangunan tersebut harus terlindung dari pandangan orang lain, terlindung dari panas, dan hujan serta terjamin privasinya; 2 ). Bangunan kakus ditempatkan pada lokasi yang tidak sampai mengganggu pandangan, tidak menimbulkan bau, serta tidak menjadi tempat hidupnya berbagai macam binatang; 3). Bangunan kakus mempunyai lantai yang kuat, mempunyai tempat berpijak yang kuat; 4). Mempunyai lubang closet yang kemudian melalui saluran tertentu dialirkan pada sumur penampung dan atau rembesan; 5). Menyediakan alat pembersih (air ataupun kertas) yang cukup, sedemikian rupa sehingga dapat segera dipakai setelah melakukan buang kotoran (Azwar, 1983). 


\section{Sarana Pembuangan Sampah}

Dari hasil pengamatan pada seluruh sekolah dasar di Kecamatan Wayhalim Kota Bandar Lampung, diketahui bahwa seluruhnya gelah memiliki tempat penampungan sampah. Namun, belum seluruhnya memiliki tempat sampah di setiap ruang kelas, sehingga memungkinkan siswa dan siswi membuang sampah sembarangan. Kotak sampah juga tidak dilengkapi dengan penutup, serta peletakkan tempat pembuangan/pengumpulan sampah sementara lebih dari 10 meter.

Menurut Keputusan Menteri Kesehatan RI Nomor 1429 tahun 2006, pembuangan sampah harus memenuhi persyaratan sebagai berikut:

a. Disetiap ruang harus tersedia tempat sampah yang dengan penutup

b. Tersedia tempat pengumpulan sampah sementara (TPS) dari seluruh ruangan untuk memudahkan pengankutan atau pemusnahan sampah

c. Peletakkan tempat pembuangan atau pengumpulan sampah sementara dengan ruang kelas berjarak minimal 10 meter.

Berdasarkan konstruksinya, tempat sampah belum memenuhi syarat seperti tidak mempunyai tutup, sehingga dapat mengundang vektor dan tikus. Seluruh sekolah dasar membuang sampah di TPS, namun sebanyak $57,1 \%$ jaraknya lebih dari 10 meter. Tempat sampah harus memenuhi peryaratan, yaitu konstruksi harus kuat dan tidak mudah bocor, memiliki tutup dan mudah dibuka tanpa mengotori tangan, dan ukuran sesuai sehingga mudah diangkut oleh satu orang.

TPS sebaiknya dibangun diatas permukaan tanah dengan ketinggian bangunan setinggi kendaraan pengangkut sampah. Menurut Chandra (2007), beberapa persyaratan yang harus dipenuhi, antara lain memiliki dua pintu, memiliki lubang ventilasi yang tertutup kawat halus untuk mencegah lalat dan binatang lain masuk kedalam dipo, ada kran air untuk membersihkan, mudah dijangkau.

Pengelolaan sampah yang kurang baik dapat memberikan pengaruh negatif bagi kesehatan dan lingkungan (Sumantri, 2010). Pengaruh terhadap kesehatan antar lain: a) Pengelolaan sampah yang kurang baik akan menjadikan sampah sebagai tempat perkembangbiakan vektor penyakit, seperti tikus dan lalat; b) Insidensi penyakit demam berdarah Dengue akan meningkat karena vektor penyakit hidup dan berkembang biak dalam sampah kaleng ataupun ban bekas yang berisi air hujan; c) Terjadinya kecelakaan akibat pembuangan sampah secara sembarangan, misalnya luka akibat benda tajam seperti besi, pecahan kaca, dan sebagainya; d) Gangguan psikosomatis, misalnya sesak nafas, stres dan lain-lain.

Sedangkan pengaruh terhadap lingkungan antar alain: a) Estetika lingkungan menjadi kurang sedap dipandang mata; b). Proses pembusukan sampah olch mikroorganisme akan menghasilkan gas-gas tertentu yang menimbulkan bau busuk; c) Pembakaran sampah dapat menimbulkan pencemaran udara dan banyak kebakaran yang lebih luas; d) Pembuangan sampah kedalam saluran pembuangan air akan menyebabkan aliran air terganggu dan saluran air menjadi dangkal; c) Apabila musim hujan datang, sampah yang menumpuk dapat menyebabkan banjirr dan mengakibatkan pencemaran pada sumber air permukaan atau sumur dangkal; e) Air banjir dapat mengakibatkan kerusakan pada fasilitas mayarakat, seperti jalan, jembatan, dan saluran air.

\section{Sarana Pembuangan Air Limbah}

Hasil penelitian mendapatkan bahwa sebanyak $57,14 \%$ menggunakan saluran pembuangan air limbah (SPAL) terbuka. Hal ini dapat menjadi tempat perindukan vektor penyakit. Menurut Keputusan Menteri Kesehatan RI Nomor 1429 tahun 2006, saluran pembuangan air limbah harus memenuhi persyaratan:

a. Tersedia saluran pembuangan air limbah yang terpisah dengan saluran penuntasan air hujan

b. Saluran pembuangan air limbah harus terbuat dari bahan kedap air dan tertutup

c. Keberadaan SPAL tidak mencemari lingkungan

d. Tersedia saluran pembuangan air limbah yang memenuhi syarat kesehatan kedap air, tertutup dan airnya dapat mengalir dengan lancar

e. Air limbah dibuang melalui tangki septic dan kemudian diresapkan kedalam tanahh.

f. Pembuangan air limbah dari laboratorium, dapur, dan wc harus memenuhi syarat kesehatan kedap air, tertutup dan diberi bak kontrol pada jarak tertentu agar mudah dibersihkan bila terjadi penyumbatan sehingga dapat mengalir dengan lancar. 
Air limbah sebelum dilepas ke pembuangan akhir harus menjalani pengolahan terlebih dahulu. Untuk dapat melaksanakan pengolahan air limbah yang efektif diperlukan rencana pengelolaan yang baik. Tujuan pengelolaan limbah antara lain: a) mencegah pencemaran pada sumber air rumah tangga; b) Melindungi hewan dan tanaman yang hidup didalam air; c) Menghindari pencemaran tanah permukaan; d Menghilakan tempat perkembangbiakannya bibit dan vektor penyakit.

Persyaratan pengelolaan air limbah yang diterapkan antara lain: a) Tidak mengakibatkan kontaminasi terhadap sumber-sumber air minum; b) Tidak mengakibatkan pencemaran air permukaan; c) Tidak menimbulkan pencemaran pada flora dan fauna yang hidup di air didalam penggunaannya schari-hari; d) Tidak dihinggapi vektor atau serangga yang menyebabkan penyakit; e) Tidak terbuka dan harus tertutup; f) Tidak menimbulkan bau atau aroma tidak sedap

Menurut Sumantri (2010), pengelolaan sarana air limbah yang kurang baik dapat berdampak terhadap lingkungan dan kesehatan. Air limbah yang langsung dibuang ke air permukaan (misalnya, sungai dan danau) tanpa dilakukan pengolahan dapat mengakibatkan pencemaran air ini. Sebagai contoh, bahan organik yang terdapat dalam air limbah bila dibuang langsung ke sungai dapat menycbabkan penurunan oksigen yang terlarut (dissolved oxygen) di dalam sungai tersebut.

Air limbah juga dapat mengandung bibit penyakit yang dapat menimbulkan penyakit bawaan air (walerbone disease). Selain itu, didalam air limbah mungkin juga terdapat zatzat berbahaya dan beracun yang dapat menimbulkan gangguan kesehatan bagi makhluk hidup yang mengkonsumsinya

\section{KESIMPULAN}

Kesimpulan dari penelitian ini yaitu: Jenis sarana air bersih yang terdapat di Sekolah Dasar Se-Kecamatan Wahyalim Kota Bandar Lampung menggunakan sumur gali, sumur bor, dan PDAM kualitas air bersih sudah memenuhi syarat, Seluruh Sekolah Dasar Se-Kecamatan Wayhalim Kota Bandar Lampung sudah mempunyai tempat pembuangan sampah dan TPS, tetapi umumnya tidak memenuhi syarat kesehatan yaitu $(42,85 \%)$, sedangkan yang memenuhi syarat kesehatan adalah $(57,14 \%)$, Kondisi sarana toilet atau urinoir di Sekolah Dasar Se-Kecamatan Wayhalim Kota Bandar
Lampung pada umumnya tidak memenuhi syarat, Kondisi sarana pembuangan air limbah di Sekolah Dasar Se-Kecamatan Wayhalim Kota Bandar Lampung tidak memenuhi syarat seperti SPAL yang terbuka sebanyak $(57,14 \%)$.

\section{SARAN}

\section{DAFTAR PUSTAKA}

Adnani, Hariza, 2011. Ilmu Kesehatan Masyarakat. Muha Medika, Yogyakarta

Azwar, Azrul, 1993, Pengantar Ilmu Kesehatan Lingkungan, PT. Mutiara Sumber Widya, Jakarta.

Chandra, Budiman, 2007, Pengantar Kesehatan Lingkungan, Penerbit Buku Kedokteran EGC, Jakarta

DEPKES RI, Permenkes No. 416 Tahun 1990, Tentang Syarat-Syarat dan Pengawasan Kualitas Air, Departemen Kesehatan RI.

DEPKES RI, 1989, Pengawasan Penyehatan Lingkungan Pemukiman, Jakarta.

DEPKES RI, 1982, Usaha Kesehatan Sekolah, Jakarta.

DEPKES RI, 1990, Ruang Lingkup Kesehatan Masyarakat, Pusat Pendidikan Tenaga Kesehatan. Jakarta.

DEPKES RI, 2007. Pengendalian Teknis Pengendalian Faktor Risiko Kesehatan Lingkungan di sekolah, Jakarta.

DINKES, 2012, Profil Kesehatan Kabupaten Pesisir Barat Tahun 2013, Lampung.

Dimyati, Ahmad. 2012. Fasilitas Sanitasi Sekolah Di Sekolah Dasar Negeri Kecamatan Pesisir Selatan Kabupaten Pesisir Barat Tahun 2015.

Ehler, V.M Dan Steel, E.W. 1980. Hygiene Dan Sanitasi, Jhon Willy \& Sons Inc, New York.

Entjang, Indan. 2000. Ilmu Kesehatan Masyarakat. PT. Citra Aditya Bakti. Bandung.

Gumelar, Danan, Catur.2014. Sarana Sanitasi Di Sekolah Dasar Negeri Sekecamatan Metro Kibang Kabupaten Lampung Timur. Poletkes Kemenkes Tanjung Karang.

Hendrik L. Blum. 1974. Derajat Kesehatan. Jakarta.

KEPMENKES RI, No. 1429 tahun 2006, Tentang pedoman Penyelenggaraan Kesehatan Lingkungan Sekolah, Jakarta.

Mustafa. 2000. Sanitasi Pembangunan. Jakarta. 
Notoatmodjo, Soekidjo, 2011, Kesehatan Masyarakat Ilmu Seni, Rineka Cipta, Jakarta.

Sanropie, Djasio; dkk, 1984, Penyediaan Air Bersih, Departemen Kesehatan RI, Jakarta, 427 halaman.

Sumantri, Arif, 2010, Kesehatan Lingkungan, PT.Fajar Interpratama Mandiri, Jakarta, 318 halaman.

http://bapelkescikarang.or.id/bapelkescikarang/ images/stories/KurmodTTG/pengolahanair limbah/mi-

$46 \% 20$ modul $\% 20$ pembuatan $\% 20$ spal\%20s ederhana.pdf.

Tim Penyusun, 2013, Pedoman Teknis Penulisan Karya Tulis Ilmiah, Politeknik Kesehatan Jurusan Kesehatan Lingkungan, Tanjung Karang.

Wardhana, W. A. 2004. Dampak Perencanaan Lingkungan. Yogyakarta, ' Andi Yogyakarta. 